\title{
Export Credit Insurance and the Debt Crisis
}

\author{
by H. H. Hashek*
}

The community of nations experienced from 1945 to the beginning of the seventies an unprecedented period of growth. Never in history has it been possible to ameliorate the living conditions of mankind in so short a period so generally and profoundly. Jean Fourastié - the French economist and sociologist - spoke of the "the glorious thirty" and quite rightly so.

This growth period has its basis in a general tendency of liberalizing the international exchanges of goods and services. It took place regardless of the economic order of the individual nations.

Many observers believe that this growth period is due to very special circumstances such as huge unsatisfied demand from consumption and investments originating in the reconstruction effort after World War II and viewed in a long-term historical perspective constitutes a unique exception to an historical growth pattern which averages rates of the order of one percent, the repetition of which in the future will neither be likely nor even possible.

The development of the world economy during the seventies and eighties seems to confirm this pessimistic view. The gloomy prophecies of the Club of Rome in 1973, in particular, could only have attracted such intensive public attention if they conformed to a drastic change in mood. After all, all they said was that exponential growth tends to develop towards infinity, which has been known since the concept was discovered in the second half of the 17th century - interestingly enough on an interest rate model. Fortunately, every element of the forecast has been proved wrong in the meantime; population growth particularly has not been following the exponential growth pattern, thus depriving the whole concept of its very basis.

This change in expectations - which is one of the most important factors in economic development - was, however, also the consequence of a decisive change in the balance of power between the two superpowers; with the erosion of the overwhelming status of the US in political power terms, it resorted to using its still unchallenged economic superiority as political leverage.

The results of this change in climate are well known: the destruction of the world's financial system which had safeguarded the economic expansion of the world economy, surging inflation, sky-rocketing interest rates, currency fluctuations, contraction of growth rates

\footnotetext{
* Chairman and General Manager, Österreichische Kontrollbank, Vienna, Austria.
} 
leading to the devastating effects of the recent recession and the development of the international debt crisis.

What was the role of export credit insurance and export financing in this environment?To put it as bluntly and as controversially as possible: it contributed further to destabilizing and increasingly volatile world economy.

What was and is the weight of credit insurance in world trade - is it large enough to count? What was and will be the relationship of credit insurance to financing a - hopefully growing world economy, and in particular the investment required to effect the structural changes in the world economy which are dangerously threatened in a growing mood of protectionism and consequent petrification?

In 1984 the members of the Berne Union covered business equivalent to approximately \$ 200 billion a year and the total volume of guarantees outstanding amounted to $\$ 350$ billion.

Total world trade was $\$ 1,910$ billion. The volume of exports of manufactured goods amounted to $\$ 1,155$ billion $(60.5 \%)$; the total of exports of manufactured goods from the industrial countries to the outside world to $\$ 690$ billion. The ratio of total exports covered varies from country to country between 30 and 50 percent.

All this indicates the substantial weight of export credit insurance in the development of world trade and on the basis of such insurance of the provision of financing to fuel international exchanges of goods and services.

In view of its importance it is surprising how insignificant was the importance attributed to one of the major factors in the development of international exchanges.

To explain this strange relationship it is useful to look briefly into the history of export credit insurance and export financing as a tool and instrument to facilitate international exchanges. The term facilitate is used and not promote, because the excessive use of these instruments for export promotion is one of the reasons for their degradation as a tool in international economic policy. One cannot repeat often enough the banality that exports mean imports at the other end.

Trade credit insurance was a byproduct of the industrial revolution. It developed when non-banking entities started to extend credit among themselves without the intervention of banks. This development was contrary to one of the basic philosophies in risk management which is that risks can be minimized by maximizing their diversification - a principle which has lost none of its importance to the present day.

Trade credit insurance, when it was invented, provided such diversification and allowed that the price for risk coverage be lowered to the benefit of both the insurer and the insured. Trade credit insurance had to deal during its first period only with short-term and with commercial risk even though from the beginning it was extended to cover domestic as well as international transactions. It was an instrument developed by the private insurance business to cover a demand within the financial markets.

This institutional framework changed radically after World War I and the beginning of the Great Depression when the hitherto non-existing "political" risk(the risk of proper execution of contractual obligations beyond the responsibility of the contracting parties) differentiated the risk element between the domestic and international trade credits. The advent of 
the political risk meant the possibility of risk diversification and became severely limited maximally to the number of sovereign nations participating in international exchanges.

When export promotion became the issue of the day - again, conveniently overlooking that each export transaction means by definition also an import transaction at the other endtrade credit insurance, an instrument which was developed to facilitate international exchanges, became an instrument to promote exports. Governements intervened and usurpated trade credit insurance as a tool of international trade policy.

Export financing was originally an exclusive domain of the banks. After World War I the emphasis of international lending in the context of trade transactions shifted to trade credits: the primary borrower became the exporter, export financing became a domestic business. Credit policy was concerned with ways and means to ease credit availability to exporters at lowthat is directly or indirectly subsidized - interest rates.

During the thirties, all major industrialized nations created export credit insurance institutions which were distinctly separated from export financing - with one major exception, the U.S. The Export Import Bank was created as a merchant bank.

The banking crisis at the beginning of the thirties brought into being another important factor for future development the division between two groups of banks: those operating in the short-term and those operating in the long-term field. Export financing resorted to the commercial or clearing banks as they came to be known.

This was the institutional framework at the beginning of the glorious thirty. Basically it has not changed since.

Export credits, however, began to play an important role in the institution of international capital markets either because they were not (or not yet) available to borrowers who needed to finance structural investments in the broad sense of the word or - because of ideological reasons - borrowers did not turn to them after they became available.

The tool to deal with such demand when seller markets turned into buyer markets (credit terms lengthened, and increased competition among exporting nations started) was in the late fifties the invention of the buyer credit formula.

Within the given framework, in the vast majority of cases export credit insurers were given the task to insure buyer credit risks and commercial banks to channel the funds. Due to the history of their formation both looked upon and treated buyer credits as a substitute for trade credits, something like a detour to arrive at the same goal.

International co-operation in the field of credit insurance started early. The famous Berne Union celebrated last year its 50th anniversary. It was founded by trade credit insurers and the attention it gave to buyer credits later largely dealt with the problem of to what extent buyer credits were conflicting with the established and accepted rules which had been very successfully developed for trade credits.

There is, however, an essential difference between these two types of operation. Basically the credit risk analysis in the case of trade credits is rooted in the insurance principle of large numbers; buyer credits basically require project analysis of a type the international and interregional institutions undertake - a task neither the credit insurers nor, in the majority of cases (the Export Import Bank being among the most important exceptions) the commercial banks involved are equipped to deal with. 
When intergovernmental co-operation was put into effect within the OECD the only facet of the multitude of problems this co-operaion could have been interested in was to limit competition between exporting nations and in whatever agreements reached, trade credits and buyer credits were and are treated synonymously.

As we know now from experience - or should know - it makes a lot of difference in a project whether it is only a good deal for the exporter and the exporting country, regardless of whether it is economically justified and can be repaid over a given period from the cash-flow it creates, or if it is also a good deal for the importer and the importing nation. One may say that this is a paternalistic approach - and indeed it has been said so. Much waste of precious capital investment could have been avoided. Taking the flood of short-term private credit into account which occurred in the seventies the debt mountain would be a few layers smaller.

Let us turn to the development of the debt crisis. It is estimated that the total debt of the non-industrial world has reached $\$ 900$ billion by the end of the year 1985 . These are large numbers. Are they? The world product has reached $\$ 12$ trillion annually. The defence expenditures of the two superpowers only are estimated to amount to $\$ 700$ billion annually as a minimum. Were it possible to reduce spending only by ten percent or freeze it at current levels only for one year (to be less illusionary) it would be possible to waive the whole interest burden to the developing world for one year.

From all this, one conclusion may be drawn: substantial as the total amount of international indebtedness of the non-industrial world is, it is manageable when viewed in the global perspective, and as a global problem. It can only be solved by global measures embedded in international co-operation.

It should be noted that only about one third of the above-mentioned international indebtedness originated from the financing of the transfer of goods and services. The remainder is due to interest rate fluctuations and the appreciation of the dollar. Therefore, a large portion of the debt is due to an autonomous growth which did not involve the transfer of goods and services. This fact makes the consolidation so difficult because the part of the debt which grew autonomously lacks the equivalent of investments to generate income to service the debts regardless of whether the original lending met this purpose or not.

The debt crisis and the oil crisis of the seventies are closely interrelated. The excalation of oil prices had the effect of a sales tax levied by the oil producers on the rest of the world which led to financial surpluses of hitherto unknown dimensions which were decoupled from the transfer of goods and services. One tends to underestimate today the danger to the world economy of this process. It could have led either to a serious deflationary development or to a further reduction in the supply of oil and with it further price increases of this strategic source of energy.

This danger was averted through what is called the "recycling" of the financial surpluses. Recycling was carried out through the private financial markets. It was done on several assumptions: that sovereign risks cannot be insolvency risks; that potentially short term commitments will remain short term regardless of whether the substitution of one creditor by another continues to exist or not. Both of these assumptions were challenged. When the solvability of a sovereign risk is challenged a chain reaction is set off and the substitution of creditors ceases to take place. 
It should be noted, however, that at the time no alternative was offered. It is useful to read again the forecasts which were then published and to remember how seriously the situation was evaluated. In hindsight, when the allocation and redistribution of responsibilities is discussed, the evaluation is quite different.

At that time, export financing institutions could have assumed a much more important role in channeling financial surpluses into the Third World. The lending of such agencies on the whole increased only moderately. Only very few started to turn to the financial markets to help to asorb the financial surpluses which were available. The fact that most agencies lent through commercial banks made it difficult to introduce project evaluation and the trade credit view of the insurance agencies exacerbated this deficiency. In the OECD, as indicated, attention was given to how to limit credit terms and how to impose thresholds on minimum interest rates. Development of criteria for project financing and distinguishing between bridge financing of serially-produced goods and projects were never seriously discussed. There was no serious attempt to develop co-financing from the part of the export finance agencies nor one should not forget - was the idea especially welcomed by the international and interregional banks themselves which looked down on export financing and insurance agencies as plebeians among the selfrighteous aristocrats in development finance.

Let me add here a personal note. I had the honor to serve as president of the Berne Union in 1972 and 1973 during the time of the first oil crisis. With the assistance of my friends I had hoped to achieve two goals: permanent reform of the Union to expand its focus from export credit to investment and financing; to establish a working relationship between the IMF and the World Bank in monitoring the direction and the quality of financial flows from the industrial to the Third World. Half of the first goal was achieved. Co-operation between the financing agencies was not achieved. As regards co-operation with the Bank and the Fund, it remained what it had been before: representatives of the Bank and the Fund participate in country discussions at the Annual Meeting where their contributions are highly appreciated.

The result of these developments is documented in the composition of international financial transfers to the developing world. In 1970 private and official export credits amounted to $\$ 2.7$ billion, in 1983 to $\$ 7.6$ billion. Bank and bound lending in 1970 amounted to 3.3 billion, and in 1983 to $\$ 36.5$ billion. Export credits declined at the height of the debt crisis from a total of $\$ 13.6$ billion in 1980 to the $\$ 7.6$ billion mentioned above!

For several reasons, there is no question that in the debt consolidation process the lead has to come from the United States. Leaving all political implications aside, which is of course not really possible, the U.S. produces one quarter of the world product, its banking institutions share a substantial part of the debt mountain, and more than three thirds of the outstanding debt are denominated in US dollar.

The official policy of the US towards the debt problem has been that of neglect; it remains to be seen whether this was benign or not. But there has been recently a decisive change. First came the G'Five agreement on exchange rate policy. Second the proposals of the U.S. Secretary of the Treasury in Seoul during October 1985.

The Baker proposal is not remarkable in its content, it is remarkable because it was made. For the first time a concerted effort was advocated for measures - regardless of their, let me put it cautiously, haziness - for positive action. It also must mean that generally sovereign risks are not regarded as potential insolvency risks otherwise it would be even more difficult to understand why the private banks should be invited to bear the main burden of the new financial 
package which should be made available; of course, another, a rather cynical reasoning could be put forward: that the banks lend to pay themselves - which is certainly not true individually.

There is little doubt, however, that the provision of $\$ 30$ billion of new funds of which $\$ 10$ billion are contingent does not solve the problem. In order to solve it, growth of the world economy is needed. This can only come about by increased international exchanges. These need to be financed. But this finance will come forth only if a permanent solution of the existing debt, in particular the floating part of it, can be found. A number of proposals have been put forward to achieve this. The main thrust of efforts should be directed towards a substitution of floating interest rates by fixed ones, perhaps by guaranteeing such a fixed rate through the debtor governments thus allowing the creation of a market for these credits and cushioning the size of the discounts which would develop and burden the profit and loss accounts of the banks.

As for new lending much closer co-operation between export credit and insurance agencies, the international and interregional and the commercial banks is required. Co-financing should be institutionalized for project financing, a syndicated form of cooperation should be established among export lending agencies allowing them to subscribe in total a fifty or more percent share of project costs which could be shared at the terms and conditions of World Bank lending among the exporting countries willing, from the view point of their experience and competitiveness, to supply goods and services to be imported, so that the time-consuming process of putting financial packages together could be considerably enhanced. Thus the extremely damaging effect of trying to separate concessionary from non-concessionary lending which has been forced upon the non-believers at the OECD could be avoided! This, by the way, seems to be another example of conflicting policies being advocated without reference to the global issues at stake. The necessary refinancing could be done through borrowing in the international financial markets of the export financing agencies, financial markets which are indeed of triple-A borrowers rather than being overwhelmed by their number.

Export credit insurance will have to conform to such procedures, in particular, by accepting project analysis and monitoring through the international and interregional banks because there is no objective reason to believe that this work could be performed better or at greater speed if it is repeated over and over again.

It was rather illogical in the past to reduce long-term lending at fixed interest rates by export financing institutions and force the commercial banks to take on the longer end. They tried - unsuccessfully, as experience shows - to escape the fact that their funds become illiquid through juridical means. But whether or not maturities can be met is not only a question of contractual obligation but depends much more on the ability to fulfil such obligations. A different strategy should be applied. The commercial banks should be invited to buy the shortterm maturities of such longer-term financing.

What is needed in short are not new institutions but a concerted effort by the existing ones to step up co-operation and - in some cases, as in financing - start it. Export financing and export insurance agencies should be aware of the fact that their loans, to a much larger degree than in the past, substitute investment credits - these are repaid from cash-flows they generate; to extend them on arbitrary maximum repayment terms invites - should these not conform with the anticipated cash-flows - rescheduling at the time of signature. Above all, it should be clear that risk and liquidity in lending can be separated in institutional treatment, risk being the domain of the insurers, liquidity being that of the banks - but that they 
constitute inseparable aspects of any lending activity so that intimate co-operation is needed between the institutions when these two aspects are institutionally separated.

The discussion to clearly divide non-concessionary from concessionary lending as it is currently undertaken by the OECD overemphasizes the aspect of competition in credit terms as if the total demand for investment goods to be bought on credit would be too low. This might be the case in the industrial world; it is clearly not in the Third World.

All of the preceding intends not to suggest that export financing in concurrence with export credit insurance could bring about a solution by itself. It could, however, and should contribute substantially to a solution; certainly not by reducing its activities - as is done currently - but by expanding them within the framework of a global approach. That the Baker proposal of Seoul did not even mention that possibility exemplifies a strange paradox - not the only one in this world. ${ }^{1}$

1 The subject of export credit insurance seems to have been raised at a meeting at the International Institute of Finance in Washington on later October 1985 following Seoul, when Mr. Davis Mulford, Assistant Secretary in the U.S. Treasury, gave details of the Baker initiative to a group of the 60 largest commercial bank creditors (Neue Zürcher Zeitung, October 31, 1985; p. 13. "Bakers Initiative auf dem Prüfstand der Banken"). 